\title{
Kekuatan Tekan Sejajar dan Geser Kayu Ulin (Eusideroxylon Zwageri) di Kota Pekanbaru Berdasarkan SNI 7973:2013
}

\author{
Marlaily Idris ${ }^{1)}$, Alfian Kamaldi ${ }^{2)}$, Andre Novan ${ }^{3)}$ \\ ${ }^{1)}$ Mahasiswa Jurusan Teknik Sipil, Fakultas Teknik, Universitas Riau \\ ${ }^{2}$ Dosen Jurusan Teknik Sipil, Fakultas Teknik, Universitas Riau \\ Kampus Bina Widya Jl. HR Soebrantas KM 12,5 Pekanbaru, Kode 28293 \\ Email : marlaily.idris@student.unri.ac.idakamaldi@yahoo.co.id, andrezayyubi@yahoo.com
}

\begin{abstract}
Wood is one of the building materials that has long been recognized by our society and has been used for various purposes, including as a support for building structures. Plants that have the Latin name Eusideroxylon zwageri Teijsm belong to the Lauraceae tribe. Ulin wood is known as strong class I wood and durable class I so it has many benefits and is very popular with the community. The purpose of this study is to examine the scientific and mechanical properties of Ulin wood so that it can obtain a modulus of flexural elasticity, flexural strength, compressive strength, shear strength and can be classified according to SNI 7973: 2013. In this study there are two variations, namely compressive strength dry air and dry oven. The results obtained were that the parallel compressive strength of Ulin wood was greater if the Ulin wood was in an oven dry state rather than air dried, with a value of compressive strength parallel to oven dry fiber $26.69 \mathrm{MPa}$ and air dry $17.58 \mathrm{MPa}$. While the results of larger shear strength are air dry than oven dry with value of $3.04 \mathrm{MPa}$ and oven dry $2.81 \mathrm{MPa}$.
\end{abstract}

Keywords: Ulin wood, air dry compressive strength, oven dry compressive strength, shear strength.

\begin{abstract}
Abstrak
Kayu adalah salah satu bahan bangunan yang sudah lama dikenal oleh masyarakat kita dan telah dipakai untuk berbagai keperluan, termasuk sebagai pendukung struktur bangunan. Tanaman yang memiliki nama latin Eusideroxylon zwageri Teijsm ini tergolong kedalam suku Lauraceae. kayu Ulin dikenal sebagai kayu kelas kuat I dan kelas awet I sehingga memiliki banyak manfaat dan sangat diminati masyarakat. Tujuan penelitian ini adalah mengkaji sifat sifik dan mekanik dari kayu Ulin tersebut sehingga bisa mendapatkan nilai modulus elastisitas lentur, kuat lentur, kuat tekan, kuat geser dan bisa di klasifikasikan berdasarkan SNI 7973:2013. Dalam penelitian ini terdapat dua variasi yaitu kuat tekan kering udara dan kering oven. Hasil yang didapat yaitu kuat tekan sejajar kayu Ulin lebih besar apabila kayu Ulin dalam keadaan kering oven daripada kering udara, dengan nilai kuat tekan sejajar serat kering oven 26,69 MPa dan kering udara 17,58 MPa. Sedangkan hasil kuat geser lebih besar kering udara daripada kering oven dengan nilai kering udara 3,04 MPa dan kering oven 2,81 MPa
\end{abstract}

Kata Kunci : kayu ulin, kuat tekan kering udara, kuat tekan kering oven, kuat geser.

\section{PENDAHULUAN}

Kayu adalah salah satu bahan bangunan yang sudah lama dikenal oleh masyarakat kita dan telah dipakai untuk berbagai jenis bangunan seperti rumah, jembatan dan menara. Sebagai bahan konstruksi bangunan, kayu sudah banyak dipakai sebelum orang mengenal beton dan baja. Kayu merupakan bahan konstruksi yang memiliki berat jenis yang ringan sehingga berat sendiri struktur menjadi ringan, setiap jenis kayu mempunyai berat jenis yang berbeda, berkisar antara minimum 0,2 $\mathrm{kg} / \mathrm{cm}^{3}$ (kayu balsa) hingga $1,28 \mathrm{~kg} / \mathrm{cm}^{3}$ (kayu nani). Semakin besar berat jenis kayu, umumnya semakin kuat pula kayunya dan semakin kecil berat jenis kayu, akan berkurang pula kekuatannya. Selain itu, menurut Tjondro (2014) bangunan dari kayu menunjukkan ketahanan yang baik terhadap gempa walaupun merupakan non-engineered building. Hal ini dikarenakan massa yang ringan sehingga menghasilkan gaya inersia yang kecil akibat gempa dengan rasio kekuatan/massa yang besar.

Perkembangan peraturan kayu di Indonesia dari PPKI 1961 hingga kini menjadi SNI 7973:2013 memberikan warna baru pada konstruksi kayu Indonesia. Pada peraturan PKKI NI-5 1961 kelas kuat kayu dikenal dengan sebutan kelas I, kelas II, kelas III, kelas IV dan kelas V. Tahun 2002, Badan Standarisasi Nasional mengeluarkan peraturan baru sebagai revisi PKKI NI-5 1961 dan menggolongkan kelas kuat kayu secara masinal (grading machine) pada kandungan air standar $15 \%$ yaitu NI-5 SNI 2002, dimana dalam penggolongannya 
menggunakan klasifikasi E10 sampai E26. Adapun peraturan yang berlaku saat ini adalah peraturan SNI 7973-2013 yang menggunakan desain ASD dan LRFD. Peraturan yang ada di Indonesia saat ini mengacu pada peraturan National Design Spesification (NDS) dari Amerika. Peraturan ini menggunakan klasifikasi daei E5 sampai E25.

Pemilihan kayu ulin sebagai benda uji karena termasuk kayu yang memiliki kelas kuat I dan kelas awet I, namun belum adanya penelitian yang mengkaji tentang pemamfaatan kayu tersebut untuk keperluan struktural. Kayu ini banyak dijumpai di Pekanbaru namun masih dimanfaatkan sebagai bahan bangunan, seperti konstruksi rumah, jembatan, tiang listrik, panel pintu, jendela. Berdasarkan uraian tersebut, maka penelitian ini perlu dilakukan untuk mengetahui mutu kayu ulin berdasarkan kuat tekan sejajar serat kering udara dan kering oven berdasarkan SNI 7973:2013.

\section{METODELOGI PENELITIAN}

\subsection{Alat dan Bahan}

Alat dan bahan yang digunakan pada penelitian ini adalah sebagai berikut:

1. Mesin UTM (Universal Testing Machine)

Mesin Hung TA HT-8503, merupakan rangkaian dari mesin uji tekan dan tarik, namun alat ini secara khusus dilengkapi dengan beban titik (dalam penelitian ini digunakan dua beban titik) dan dua tumpuan. Mesin ini dilengkapi dengan sistem komputerisasi yang baik seperti pada Gambar 1 .

Kode model alat dari mesin ini yaitu H-200A dengan beban maksimum $200 \mathrm{KN}$.

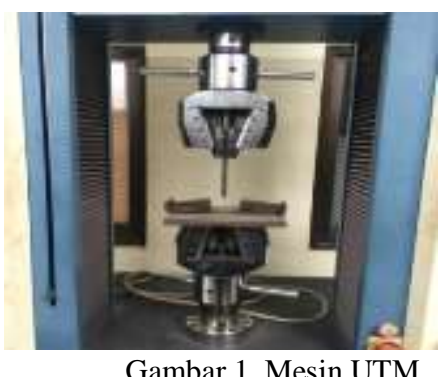

2. Timbangan 0,1 gram

Digunakan untuk Menimbang berat benda uji pada pengujian sifat fisik dengan ketelitian 0,1 gram. Timbangan dapat dilihat pada Gambar 2.

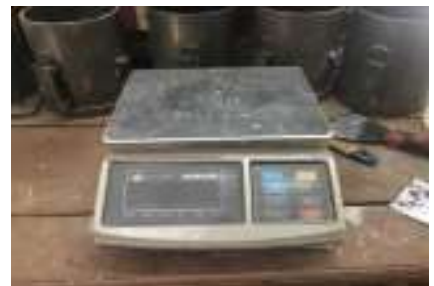

Gambar 2. Timbangan

\section{Pengekang Sampel Geser}

Pengekang dengan plat baja dan didesain berdasarkan SNI 03-3400-2002 digunakan untuk menahan benda uji geser supaya benda uji terkekang sesuai posisi dan ukuran. Alat dapat dilihat pada Gambar 3.

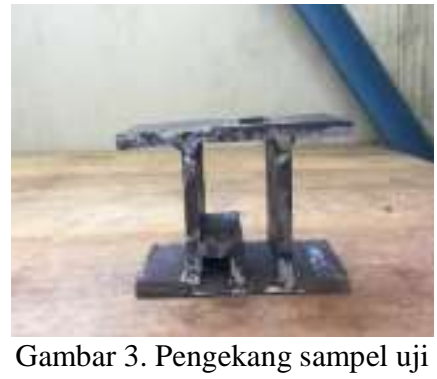

\section{Plastic wrap}

Plastic wrap digunakan untuk membungkus sampel kuat tekan kering oven dan kuat geser kering oven. Plastic Wrap dapat dilihat pada Gambar 4.

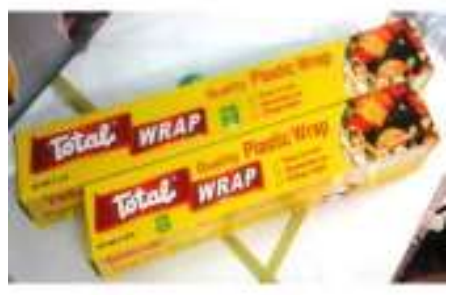

Gambar 4. Plastic wrap

\section{Silica gel}

Silica Gel berfungsi sebagai bahan pengawet yang diletakan pada bagian dalam kayu sebelum dibungkus dengan plastic wrap seperti yang terlihat pada Gambar 5.

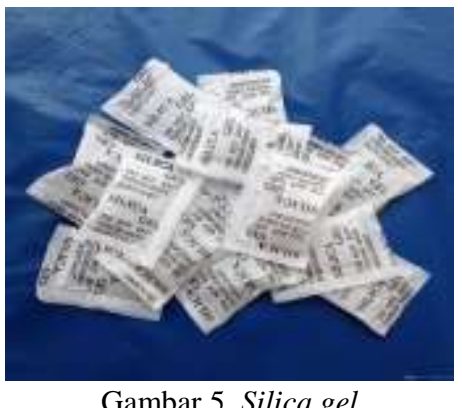

\subsection{Kuat Tekan}

Pengujian kuat tekan ini didasarkan pada SNI 03-3958-1995 dengan tujuan untuk menentukan kuat lentur dari kayu tersebut. Benda uji yang digunakan adalah benda uji dengan ukuran 50 × 50 × $200 \mathrm{~mm}$ seperti yang terlihat pada Gambar 6 berikut. 


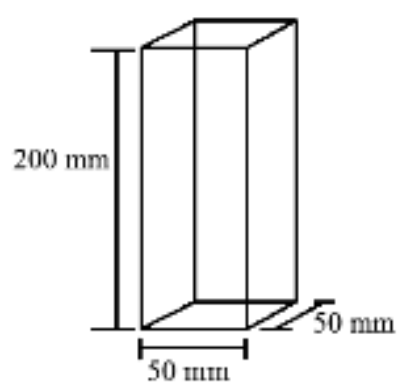

Gambar 6. Ukuran sampel benda uji kuat tekan sejajar serat

Pengujian kuat tekan sejajar serat ini terdiri dari dua variasi yaitu variasi A (Kering Udara) dan variasi B (Kering Oven). Prosedur penelitian dalam uji kuat tekan ini adalah sebagai berikut:

1. Benda uji yang digunakan pada pengujian ini terdiri dari benda uji kering udara sebanyak tiga sampel seperti Gambar 7 dan kering oven sebanyak tiga sampel. Benda uji kering oven diberikan perlakukan khusus yaitu diberikan total wrap dan silica gel supaya benda uji tetap pada kondisi kering oven seperti pada Gambar 8.

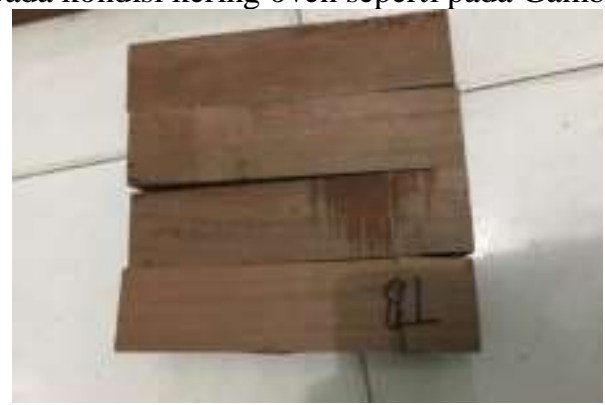

Gambar 7. Benda uji kuat tekan kering udara

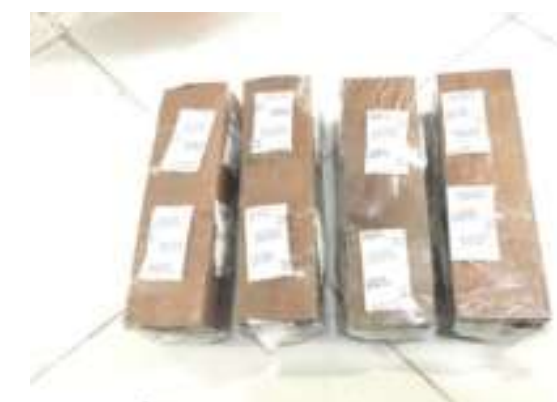

Gambar 8. Pemberian total wrap dan silica gel pada sampel kering oven

2. Penimbangan sampel kering udara dan kering oven dengan menggunakan timbangan 0,1 gram.

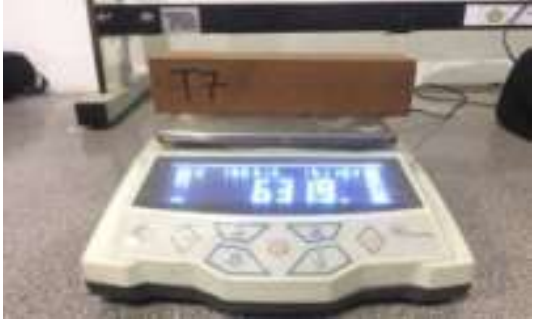

Gambar 9. Penimbangan sampel sebelum pengujian

3. Sampel kering udara dapat langsung diuji kuat tekan, sedangkan sampel kering oven di masukan ke dalam oven terlebih dahulu hingga beratnya tetap. Selanjutnya, Benda uji diletakan pada mesin UTM (Universal Testing Machine) seperti Gambar 10 dibawah ini.

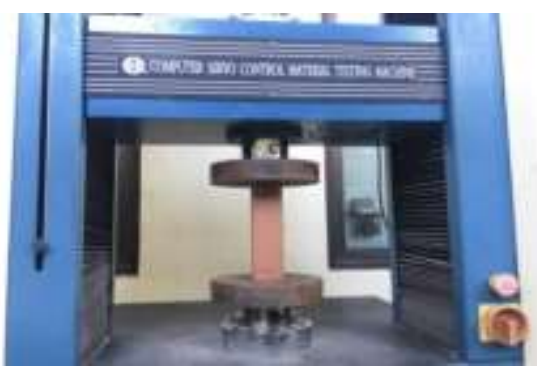

Gambar 10. Pengujian kuat tekan

4. Menjalankan mesin penguji dengan kecepatan konstan. Beban diberikan terus secara teratur sampai benda uji retak/pecah/belah. Mengamati benda uji dan mencatat hasil pengujian.

\subsection{Kuat Geser}

Pengujian kuat geser didasarkan pada SNI 03-3400-1995 dengan tujuan untuk menentukan kuat geser dari kayu tersebut. Benda uji yang digunakan yaitu berdimensi $50 \times 50 \times 65 \mathrm{~mm}$ seperti yang terlihat pada Gambar 11 berikut.

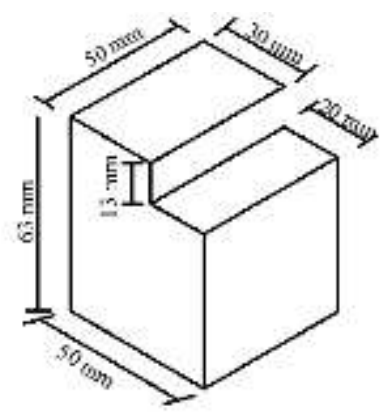

Gambar 11. Ukuran sampel kuat geser

Pengujian kuat geser ini terdiri dari dua variasi yaitu variasi A (Kering Udara) dan variasi B (Kering Oven). Prosedur penelitian dalam uji kuat tekan ini adalah sebagai berikut: 
1. Benda uji yang digunakan pada pengujian ini terdiri dari benda uji kering udara sebanyak 3 sampel seperti Gambar 12 dan kering oven sebanyak 3 sampel. Benda uji kering oven diberikan perlakukan khusus yaitu diberikan plastic wrap dan silica gel supaya benda uji tetap pada kondisi kering oven seperti pada Gambar 13.

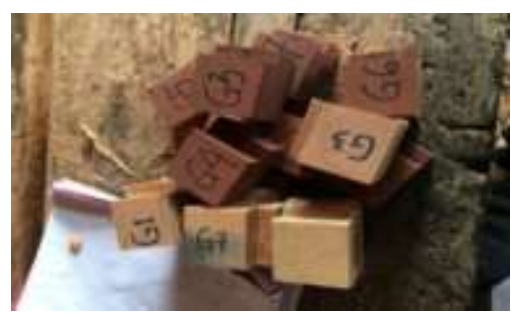

Gambar 12. Benda uji kuat geser kering udara

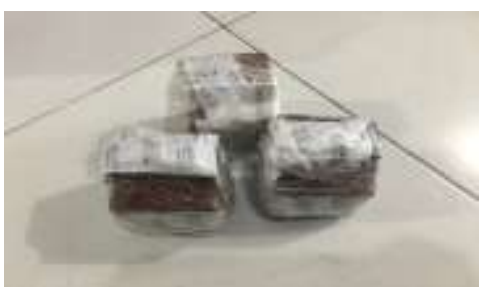

Gambar 13. Pemberian plastic wrap dan silica gel pada sampel

2. Penimbangan sampel kering udara dan kering oven dengan menggunakan timbangan 0,1 gram.

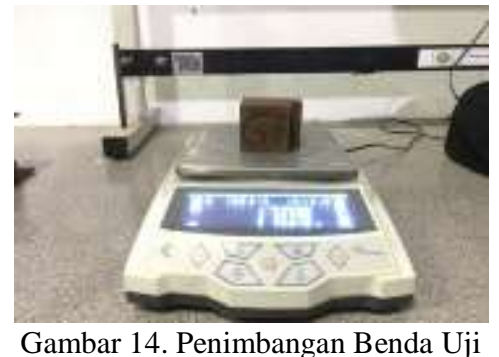

3. Sampel kering udara dapat langsung diuji kuat tekan, sedangkan sampel kering oven di masukan kedalam oven terlebih dahulu hingga beratnya tetap. Selanjutnya, benda uji diletakan pada mesin UTM (Universal Testing Machine) seperti Gambar 15.

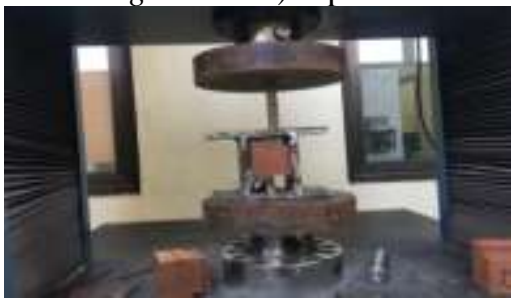

Gambar 15. Pengujian Kuat Geser

4. Menjalankan mesin penguji dengan kecepatan konstan. Beban diberikan terus secara teratur sampai benda uji retak/pecah/belah. Mengamati benda uji dan mencatat hasil pengujian.

\section{HASIL DAN PEMBAHASAN}

Berdasarkan SNI 03-3958-1995 dan SNI 03-34001995 untuk menghitung kuat tekan sejajar kayu dan kuat geser menggunakan Rumus (1) :

$$
\mathrm{F}_{\mathrm{c} / /}=\frac{\mathbf{p}}{\mathbf{b} \mathbf{x} \mathbf{h}}(\mathrm{Mpa})
$$

Dengan :

$\mathrm{F}_{\mathrm{c} / l} \quad=$ Kuat tekan sejajar serat/kuat geser $(\mathrm{MPa})$

$\mathrm{b} \quad=$ Lebar benda uji $(\mathrm{mm})$

$\mathrm{P} \quad=$ Beban uji maksimum $(\mathrm{N})$

$\mathrm{h} \quad=$ Tinggi benda uji $(\mathrm{mm})$

\subsection{Kuat Tekan Kering Udara}

Dalam pengujian kuat tekan kering udara menggunakan tiga sampel dengan kode TKU-1, TKU-2 dan TKU-3. Hasil pengujian di laboratorium menunjukan besarnya beban tekan pada sampel uji, sehingga dapat dicari kuat tekan seperti Rumus (1).

Perhitungan kuat tekan kering udara dapat dilihat pada Tabel 1 dimana didapatkan kuat tekan sejajar kayu ulin rata-rata yaitu 17,58 $\mathrm{MPa}$, Maka dapat diklasifikasikan E20 berdasarkan tabel pengklasifikasian SNI 7973:2013.

Tabel 1. Kuat tekan sejajar serat kering udara

\begin{tabular}{|c|c|c|c|c|c|c|c|}
\hline \multirow{2}{*}{ No } & \multirow{2}{*}{ Kode } & \multicolumn{2}{|c|}{ Ukuran } & \multirow{2}{*}{$\begin{array}{c}\text { Beban Tekan } \\
\text { (N) }\end{array}$} & \multirow{2}{*}{$\begin{array}{c}\text { Deformasi } \\
(\mathrm{mm})\end{array}$} & \multirow{2}{*}{$\mathrm{K}_{\mathrm{F}}$} & \multirow{2}{*}{$\begin{array}{l}\text { Kuat } \\
\text { Tekan } \\
\text { (MPa) }\end{array}$} \\
\hline & & $\mathrm{b}(\mathrm{mm})$ & $\mathrm{h}(\mathrm{mm})$ & & & & \\
\hline 1 & TKU-1 & 54,10 & 53,10 & $121.013,40$ & 2,78 & 2,70 & 17,55 \\
\hline 2 & TKU-2 & 54,74 & 52,68 & $123.972,40$ & 2,96 & 2,70 & 17,91 \\
\hline 3 & TKU-3 & 54,41 & 53,10 & $119.761,00$ & 4,50 & 2,70 & 17,27 \\
\hline \multicolumn{7}{|c|}{ Rata-Rata } & 17,58 \\
\hline
\end{tabular}

Pengujian Kuat tekan sejajar serat kering udara tersebut terjadi beberapa jenis keretakan seperti yang telah dijelaskan di dalam SNI 03-39582002. Jenis keretakan tersebut dapat dilihat pada Tabel 2.

Tabel 2. Keretakan pada sampel kuat tekan sejajar serat kering udara

No Kode Bentuk Ketetakan


Retak memanjang yang terjadi pada TKU-1 dikarenakan adanya tarik dengan arah penjalaran retak sejajar arah serat. Sedangkan pada TKU-2 terjadi retak geser dikarenakan retak menjalar dan mengikuti arah serat. Kedua tipe keretakan yang terjadi pada kayu ulin ini merupakan salah satu ciri bahwa kayu ini merupakan kayu kuat.

Selain beban tekan, dalam pengujian ini menyajikan riwayat kurva hubungan antara tegangan (MPa) dan regangan seperti pada Gambar 16. Dari grafik tersebut benda uji TKU-1 mencapai beban maksimum 41,47 MPa dan turun lalu mengalami putus (getas), TKU-2 mencapai beban maksimum pada 41,89 MPa dan turun lalu mengalami putus dan TKU-3 mencapai beban maksimum pada $40,02 \mathrm{MPa}$ kemudian mengalami dan turun naik kemudian putus.

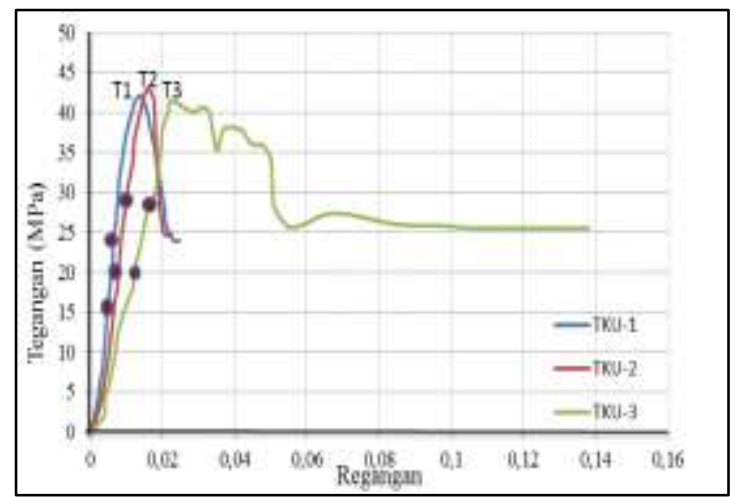

Gambar 16. Hasil pengujian tekan sejajar serat kayu ulin kering udara

Grafik hasil pengujian kuat tekan sejajar serat pada Gambar 16 dapat digunakan untuk mencari modulus elastisitas tekan sejajar serat dengan menggunakan grafik hubungan tegangan dan regangan. Hasil pembacaan grafik dapat dilihat pada Tabel 3 berikut ini.

Tabel 3. Nilai Modulus Elastisitas tekan

\begin{tabular}{cccccccc}
\hline Kode & $\begin{array}{c}\sigma_{1} \\
(\mathrm{MPa})\end{array}$ & $\begin{array}{c}\sigma_{2} \\
(\mathrm{MPa})\end{array}$ & $\varepsilon_{1}$ & $\varepsilon_{2}$ & $\begin{array}{c}\Delta \sigma \\
(\mathrm{MPa})\end{array}$ & $\Delta \varepsilon$ & $\begin{array}{c}\mathrm{E} \\
(\mathrm{MPa})\end{array}$ \\
\hline TKU-1 & 16 & 24 & 0,50 & 0,64 & 8 & 0,14 & $5.714,29$ \\
TKU-2 & 20 & 27 & 0,75 & 0,94 & 12 & 0,19 & $6.315,79$ \\
TKU-3 & 20 & 28 & 1,20 & 1,60 & 8 & 0,40 & $2.000,00$ \\
\hline \multicolumn{7}{c}{ Rata - Rata } \\
\hline \multicolumn{1}{c}{}
\end{tabular}

Hasil yang didapatkan yaitu 4.676,69 MPa. Maka berdasarkan PKKI 1961, kayu ulin memiliki modulus elastisitas tekan kelas V. Hal ini disebabkan karena pengujian modulus elastisitas tekan dilakukan hingga benda uji patah/retak sehingga nilai modulus elastisitas tekan tersebut hanya bisa dibaca melalui grafik kuat tekan sejajar serat. Seharusnya, pengujian modulus elastisitas tekan dilakukan dengan cara penekanan namun benda uji tidak mencapai patah/retak.

\subsection{Kuat Tekan Kering Oven}

Benda uji tekan sejajar serat kering oven berjumlah tiga benda uji. Terdiri dari TKO-5, TKO7 dan TKO-8 yang diberikan total wrap dan silica gel untuk menjaga suhu dari sampel tersebut dan kadar air oven dari kayu ulin dapat dilihat pada Tabel 4. Hasil pengujian di laboratorium berupa beban maksimum sehingga dapat dicari kuat tekan sejajar serat menggunakan Rumus (1) dan didapatkan hasil seperti Tabel 5.

Tabel 4. Kadar air oven pengujian kuat tekan

\begin{tabular}{cccccc}
\hline \multirow{2}{*}{ Kode } & \multicolumn{5}{c}{ Berat Benda Uji } \\
\cline { 2 - 6 } Sampel & Hari ke- & Hari ke- & Hari ke- & Hari ke- & Hari ke- \\
& 1 & 2 & 3 & 4 & 5 \\
\hline TKO-5 & 639,1 & 600,5 & 555,5 & 538 & 535,9 \\
TKO-7 & 631,9 & 595,5 & 553 & 542 & 540 \\
TKO-8 & 621,9 & 567 & 542 & 524 & 520,08 \\
\hline Kadar Air $=$ & $32,71 \%$ & $28,44 \%$ & $18,93 \%$ & $15,01 \%$ & $14,33 \%$ \\
\hline
\end{tabular}

Tabel 5. Kuat tekan sejajar serat kering oven

\begin{tabular}{cccccccc}
\hline & & \multicolumn{2}{c}{ Ukuran } & \multirow{2}{*}{$\begin{array}{c}\text { Beban } \\
\text { Tekan }\end{array}$} & $\begin{array}{c}\text { Kuat Tekan } \\
\text { Ultimit }\end{array}$ & $\begin{array}{c}\text { Kuat Tekan } \\
\text { Izin }\end{array}$ \\
\cline { 3 - 5 } & & $\begin{array}{c}\mathrm{b} \\
(\mathrm{mm})\end{array}$ & $\begin{array}{c}\mathrm{h} \\
(\mathrm{mm})\end{array}$ & $(\mathrm{N})$ & $(\mathrm{MPa})$ & & $(\mathrm{MPa})$ \\
\hline 1 & TKO-5 & 50,94 & 53,06 & $151.392,70$ & 56,01 & & 23,34 \\
2 & TKO-7 & 52,22 & 50,78 & $178.970,90$ & 67,49 & 2,40 & 28,12 \\
3 & TKO-8 & 52,23 & 50,78 & $182.213,80$ & 68,71 & & 28,63 \\
\hline \multicolumn{6}{c}{ Rata - Rata } \\
\hline
\end{tabular}

Sampel kuat tekan sejajar serat kering oven dilakukan pengujian pada saat sampel masih mengandung $14,33 \%$ air didalamnya. Perhitungan kuat tekan sejajar serat kering oven dapat dilihat pada Tabel 4 dimana didapatkan kuat tekan sejajar kayu ulin rata-rata yaitu $26,69 \mathrm{MPa}$ sedangkan pada kuat tekan sejajar serat kering udara yaitu 17,58 MPa. Dari hasil yang didapat, maka dapat disimpulkan bahwa kuat tekan sejajar kayu ulin lebih besar apabila kayu ulin dalam keadaan kering oven daripada kering udara. Berdasarkan SNI 7973:2013 yaitu nilai desain dan modulus elastisitas lentur acuan, kuat tekan sejajar serat kayu ulin kering oven terletak pada E25.

Hal ini dapat terjadi karena saat kayu mengering dibawah titik jenuh serat, sebagian besar kekuatan dan sifat elastis bertambah. Hal ini terjadi karena saat air dikeluarkan dari dinding sel, molekul-molekul berantai panjang bergerak saling mendekat dan menjadi terikat lebih kuat. Kenaikan kekuatan umumnya mulai tampak pada saat kadar air dibawah titik jenuh atau dibawah $25 \%$.

Pengujian Kuat tekan sejajar serat kering udara tersebut terjadi beberapa jenis keretakan seperti yang telah dijelaskan di dalam SNI 03-39582002. Jenis keretakan tersebut dapat dilihat pada Tabel 6. 
Tabel 6. Keretakan pada sampel kuat tekan sejajar serat kering oven

No Kode Bentuk Ketetakan

Retak memanjang yang terjadi pada TKO-8 dikarenakan adanya tarik dengan arah penjalaran retak sejajar arah serat. Sedangkan pada TKO-7 terjadi retak geser dikarenakan retak menjalar dan mengikuti arah serat. Kedua tipe keretakan yang terjadi pada kayu ulin ini merupakan salah satu ciri bahwa kayu ini merupakan kayu kuat.

Adapun Gambar 17 menyajikan grafik hubungan antara tegangan dan regangan. Pada benda uji TKO-5 mencapai puncak maksimum pada 56,01 MPa kemudian turun dan putus/retak, benda uji TKO-7 mencapai puncak maksimum pada 67,50 MPa kemudian turun dan putus/retak dan benda uji TKO-8 ,mencapai beban maksimum 64,39 $\mathrm{MPa}$ turun dan putus/retak.

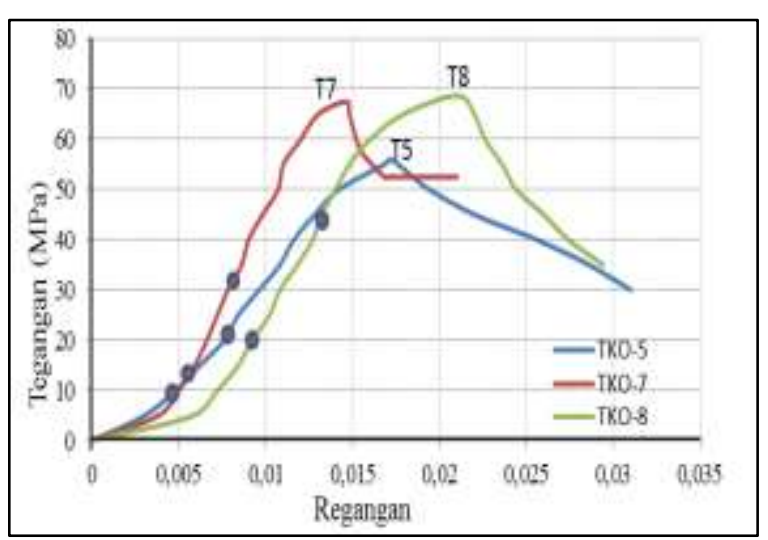

Gambar 17. Grafik pengujian tekan sejajar serat kayu ulin

Grafik hasil pengujian kuat tekan sejajar serat pada Gambar 17 dapat digunakan untuk mencari modulus elastisitas tekan sejajar serat dengan menggunakan grafik hubungan tegangan dan regangan. Hasil pembacaan grafik dapat dilihat pada Tabel 7 berikut ini.

Tabel 7. Modulus elastisitas tekan sejajar serat kering oven

\begin{tabular}{|c|c|c|c|c|c|c|c|}
\hline Kode & $\begin{array}{c}\sigma_{1} \\
(\mathrm{MPa})\end{array}$ & $\begin{array}{c}\sigma_{2} \\
(\mathrm{MPa})\end{array}$ & $\varepsilon_{1}$ & $\varepsilon_{2}$ & $\begin{array}{c}\Delta \sigma \\
(\mathrm{MPa})\end{array}$ & $\Delta \varepsilon$ & $\begin{array}{c}\mathrm{E} \\
(\mathrm{MPa})\end{array}$ \\
\hline TKO-5 & 10 & 20 & 0,48 & 0,76 & 10 & 0,28 & $3.571,42$ \\
\hline TKO-7 & 13 & 32 & 0,55 & 0,82 & 19 & 0,27 & $7.037,03$ \\
\hline TKO-8 & 20 & 48 & 0,92 & 1,38 & 28 & 0,46 & $6.086,95$ \\
\hline
\end{tabular}

Hasil yang didapatkan yaitu 5.565,13 MPa. Maka berdasarkan PKKI 1961, kayu ulin memiliki modulus elastisitas tekan kelas V. Jika dibandingkan dengan modulus elastisitas tekan pada kering udara, maka kering oven lebih tinggi. Hal ini dikarenakan kuat tekan kering oven pada kadar air 14,33\% lebih tinggi daripada kuat tekan kering udara.

\subsection{Kuat Geser Kering Udara}

Benda uji geser kayu ulin kering udara berjumlah tiga benda uji. Gambar 12 memperlihatkan benda uji tekan sejajar serat kayu ulin yang terdiri dari GKU-1, GKU-2 dan GKU-3. Pengujian di laboratorium menunjukan besarnya beban geser pada sampel uji sehingga dapat digunakan Rumus (1) untuk mendapatkan nilai kuat geser. Perhitungan kuat geser kering udara didapatkan rata-rata dari pengujian tersebut yaitu 3,04 MPa sehingga berada pada E25. Hasil dapat dilihat pada Tabel 8 .

Tabel 8. Kuat Tekan Sejajar Serat Kering Udara

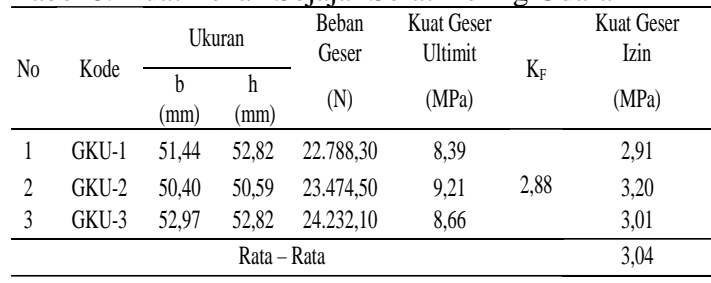

Pengujian Kuat tekan geser serat tersebut terjadi keretakan seperti yang telah dijelaskan di dalam SNI 03-3400-2002. Jenis keretakan tersebut dapat dilihat pada Tabel 9. Retak yang terjadi yaitu retak belah, retak ini disebabkan karena terjadi pada sampel arah sejajar serat yaitu vertikal.

Tabel 9. Keretakan pada sampel benda uji geser

\begin{tabular}{lll}
\hline No Kode & Bentuk Ketetakan \\
\hline GKU-2 &
\end{tabular}

Selain beban geser dalam experimental ini menyajikan riwayat kurva hubungan antara tegangan (MPa) dan regangan seperti pada Gambar 18. Dari kurva tersebut dapat dilihat bahwa benda uji GKU-1 mencapai puncak pada 7,27 MPa, GKU-2 mencapai puncak pada 9,18 MPa dan GKU-3 pada 8,48 MPa. 


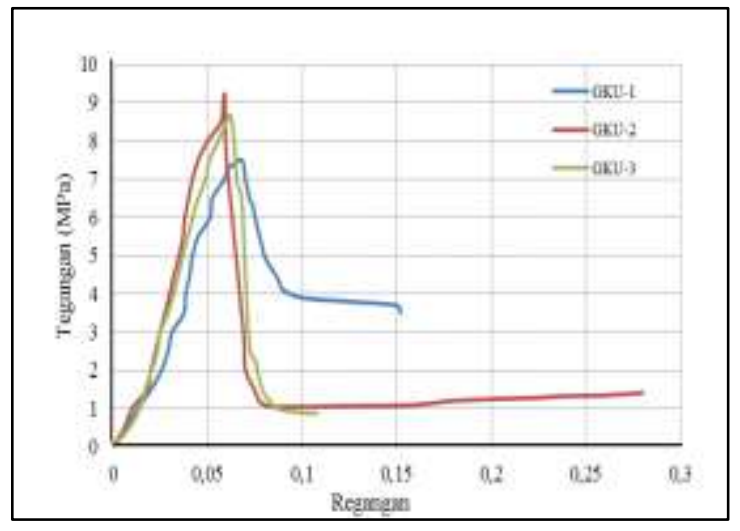

Gambar 18. Grafik pengujian geser kering udara kayu ulin

\subsection{Kuat Geser Kering Oven}

Benda uji yang digunakan pada penelitian ini dapat dilihat pada Gambar 13 dimana diberikan perlakuan khusus yaitu pemberian plastic wrap dan silica gel supaya tetap berada dalam kondisi kering oven saat dilakukannya pengujian dan nilai kadar air oven dapat dilihat pada Tabel 10.

Hasil beban maksimum yang didapat dari pengujian di laboratorium dapat digunakan untuk mendapatkan kuat geser dengan menggunakan Rumus (1) sehingga mendapatkan kuat geser.

Tabel 10. Kadar air oven pengujian kuat geser

\begin{tabular}{cccccccc}
\hline & & Berat & Hari & Hari & Hari & Hari & Kadar Air \\
No & Kode & Awal & Ke-1 & Ke-2 & Ke-3 & Ke-4 & $\begin{array}{c}\text { Pengujian } \\
(\%)\end{array}$ \\
& & (gram) & (gram) & (gram) & (gram) & (gram) & $\begin{array}{c}\text { Pran } \\
\end{array}$ \\
\hline 1 & GKO-5 & 173,10 & 139,00 & 126,80 & 123,60 & 122,70 & 41,08 \\
2 & GKO-7 & 180,20 & 139,00 & 128,60 & 124,10 & 122,50 & 47,10 \\
3 & GKO-8 & 176,70 & 142,00 & 142,00 & 132,50 & 130,80 & 35,09 \\
\hline \multicolumn{7}{c}{ Rata-Rata } \\
\hline
\end{tabular}

Tabel 11. Kuat geser kering oven

\begin{tabular}{|c|c|c|c|c|c|c|c|}
\hline \multirow[b]{2}{*}{ No } & \multirow{2}{*}{ Kode } & \multicolumn{2}{|c|}{ Ukuran } & \multirow{2}{*}{$\begin{array}{c}\text { Beban } \\
\text { Geser } \\
(\mathrm{N})\end{array}$} & \multirow{2}{*}{$\begin{array}{l}\text { Kuat } \\
\text { Geser } \\
\text { (MPa) }\end{array}$} & \multirow[b]{2}{*}{$\mathrm{K}_{\mathrm{F}}$} & \multirow{2}{*}{$\begin{array}{c}\text { Kuat Geser } \\
\text { Ultimit } \\
\text { (MPa) }\end{array}$} \\
\hline & & $\begin{array}{c}\mathrm{b} \\
(\mathrm{mm})\end{array}$ & $\begin{array}{c}\mathrm{h} \\
(\mathrm{mm})\end{array}$ & & & & \\
\hline 1 & GKO-5 & 50,20 & 50,45 & $21.750,40$ & 8,59 & \multirow{3}{*}{2,88} & 2,98 \\
\hline 2 & GKO-7 & 50,23 & 50,44 & $26.049,00$ & 10,28 & & 3,57 \\
\hline 3 & GKO-8 & 50,00 & 50,01 & $13.412,10$ & 5,37 & & 1,86 \\
\hline & \multicolumn{6}{|c|}{ Rata - Rata } & 2,81 \\
\hline
\end{tabular}

Berdasarkan perhitungan pada Tabel 11, maka didapatkan nilai rata-rata dari kuat geser tersebut yaitu 2,81 MPa dan berada pada E23 sedangkan dalam keadaan kering udara 3,04 MPa. Namun dari hasil yang didapatkan, tidak memiliki perbedaan yang besar, jadi untuk kekuatan geser arah horizontal kayu ulin tidak terlalu signifikan antara hasil kering udara dan kering oven.

Pengujian Kuat tekan geser serat tersebut terjadi keretakan seperti yang telah dijelaskan di dalam SNI 03-3400-2002. Jenis keretakan tersebut dapat dilihat pada Tabel 12. Retak yang terjadi yaitu retak belah, retak ini disebabkan karena terjadi pada sampel arah sejajar serat yaitu vertikal.

Tabel 12. Keretakan sampel benda uji geser

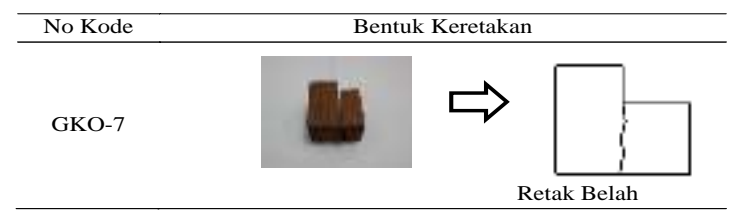

Selain beban maksimum, dalam experimental ini menyajikan riwayat kurva hubungan antara tegangan (MPa) dan regangan seperti pada Gambar 12.

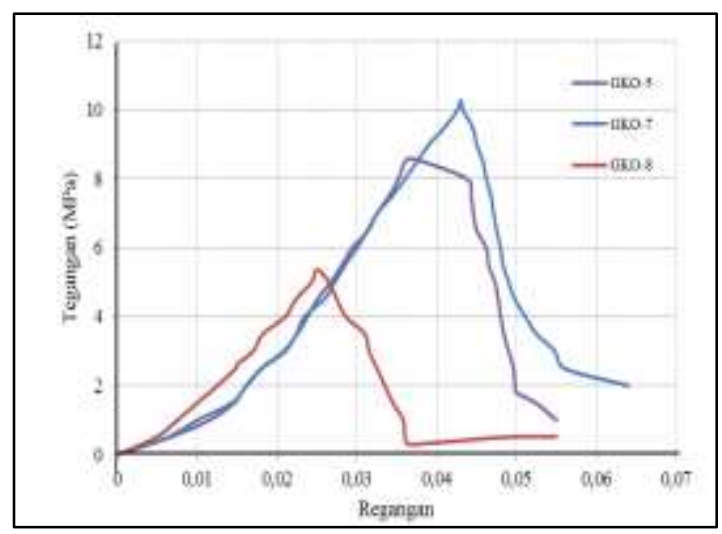

Gambar 19. Grafik pengujian geser kering oven kayu ulin

\section{KESIMPULAN}

Berdasarkan hasil pengujian kuat tekan dan kuat geser, maka dapat disimpulkan yaitu. Nilai kuat tekan sejajar kayu ulin rata-rata kering oven yaitu 26,69 MPa atau E25 sedangkan pada kuat tekan sejajar serat kering udara yaitu 17,58 MPa atau E20. Lebih besar nilai kuat tekan kering oven daripada kering udara karena saat kayu mengering dibawah titik jenuh serat, sebagian besar kekuatan dan sifat elastis bertambah. Hal ini terjadi karena saat air dikeluarkan dari dinding sel, molekul-molekul berantai panjang bergerak saling mendekat dan menjadi terikat lebih kuat. Kenaikan kekuatan umumnya mulai tampak pada saat kadar air dibawah titik jenuh atau dibawah $25 \%$.

Nilai rata-rata dari kuat geser kering oven kayu ulin yaitu 2,81 MPa atau E23 sedangkan kuat geser kering udara didapatkan rata-rata dari pengujian tersebut yaitu 3,04 MPa atau E25. Namun dari hasil yang didapatkan, tidak memiliki perbedaan yang besar, jadi untuk kekuatan geser arah horizontal kayu ulin tidak terlalu signifikan antara hasil kering udara dan kering oven.

\section{DAFTAR PUSTAKA}

[1] asyraafahmadi. (2018). Ulin pohon kayu yang memiliki diameter besar. Retrieved from 
https://asyraafahmadi.com/in/pengetahuan/mat erial/alami/non-tambang/kayu/ulin/

[2] Foresteract. (2017). Pohon ulin (Eusideroxylon zwageri): habitat, sebaran, dan status konservasi. Retrieved from https://foresteract.com/pohon-ulineusideroxylon-zwageri/

[3] NI-5 SNI 2002. (2002). Tata cara perencanaan konstruksi kayu Indonesia. Badan Standarnisasi Nasional.

[4] PKKI 1961. (1961). Peraturan konstruksi kayu Indonesia. Departemen Pekerjaan Umum.
[5] SNI 03-3400-1995. (1995). Metode pengujian kuat geser kayu di laboratorium. Badan Standardisasi Indonesia.

[6] SNI 03-3958-1995. (1995). Metode pengujian kuat tekan kayu di laboratorium. Badan Standardisasi Indonesia.

[7] SNI 7973:2013. (2013). Spesifikasi desain untuk konstruksi kayu. Badan Standardisasi Nasional. Badan Standardisasi Indonesia.

[8] Tjondro, J. A. (2014). Perkembangan dan prospek rekayasa struktur kayu di Indonesia. 